\title{
Una lucha contra la bilis negra: La Lozana Andaluza y los analgésicos del amor y la parodia
}

\author{
Juan Guardiola Morillas \\ Universidad de las Islas Baleares
}

\section{RESUMEN}

La trayectoria crítica del Retrato de La Lozana Andaluza, del presbítero cordobés Francisco Delicado, comenzó realmente hace unos decenios, siendo palpable su revalorización en nuestros días. Sin embargo, su representación de la sexualidad y el erotismo sigue siendo, como un siglo antes, materia controvertida y por elucidar. En este artículo se estudia cómo con la nominación y vivencia de lo sexual el autor y la protagonista logran atenuar su dolencia melancólica. El objetivo es enfocar este asunto erótico en el contexto de los tratados amorosos y médicos, así como de las ficciones sentimentales o celestinescas que son próximas a la obra, y ver cómo algunos tópicos, motivos y lugares comunes son subvertidos por la mano del autor con unos fines paródicos.

Palabras Clave: Francisco Delicado, La Lozana Andaluza, erotismo, melancolía, parodia.

\section{A fight against black bile: La Lozana andaluza and love's painkillers and parody}

\section{ABSTRACT}

The critical trajectory of the Retrato de La Lozana Andaluza, of the cordovan presbyter Francisco Delicado, began a few decades ago, being palpable his revaluation nowadays. Nevertheless, the representation of the sexuality and the eroticism are still, like one century ago, a neglected matter to elucidate. This article studies how with the sexual nomination and experience the author and the protagonist attenuate their melancholic disease. The purpose is focussing this sexual matter in the context of the medical and erotic treatises, or the sentimental romances and "celestinescas» which are close to the book and see how some topics, motives and common places are subverted by the author with a parodic intention.

KEY WORDS: Francisco Delicado, La Lozana Andaluza, eroticism, melancholia, parody. 


\section{Condena, olvido y estatus actual de La Lozana Andaluza}

Desde los años ochenta la historiografía literaria otorga al Retrato de la Lozana Andaluza una nueva valoración, necesaria y más ajustada. La crítica salda definitivamente, aunque tarde, la deuda contraída con la opera magna de Francisco Delicado, que había sido denostada injustamente durante largo tiempo, las más de las veces por unos motivos de índole extraliteraria. La obra del presbítero cordobés y romano ha ido saliendo poco a poco de aquel silencio al que anatemas de una franja del sector académico y de la intelectualidad decimonónica la condenaron, y no faltan ahora estudiosos a cuyos análisis se suma el imperativo añadido de rescatar a $\mathrm{La}$ Lozana del ostracismo al que la empujó tanto desdén crítico, desdén que, todo sea dicho, tuvo ocasionalmente una raíz mojigata ${ }^{1}$.

El número de enjuiciamientos, casi tantos como lectores confrontan la obra, ha crecido de forma notoria. Lecturas clásicas (Salvador Miguel 1984, Botta 2002, Joset 2005) incluían a La Lozana en la corriente celestinesca $^{2}$ o la concebían como preámbulo de la picaresca aurisecular ${ }^{3}$. Pero

1.- La censura de más peso fue sin duda la de Menéndez Pelayo (Marcelino Menéndez Pelayo, Orígenes de la novela. Edición nacional de las obras completas de Menéndez y Pelayo [1905], Madrid, Consejo Superior de Investigaciones científicas, vol. 16, 1943 —edición digital de Enrique Sánchez Reyes, Biblioteca Virtual Miguel de Cervantes: cervantesvirtual.com, pp. 45-46-). No obstante, el estudioso santanderino atinó en otros puntos: esa obra «inmunda y fea" guardaba a su vista concomitancias con los Raggionamenti de Aretino, se asemejaba en sus técnicas a ciertos cinematógrafos de su época y era claro exponente de un hibridismo genérico parecido al de la Tragicomedia. Entre vituperios, Menéndez Pelayo abrió muchos lugares comunes de los estudios lozanescos hasta hoy. Como además recuerda Allaigre, fue Menéndez Pelayo el primero en advertir la bisemia «retrato-retraer», un equívoco de sustancial importancia (véase su introducción a: Francisco Delicado, La Lozana Andaluza, Madrid, Cátedra, 1985, pp. 41-61).

2.- Aunque el mismo Menéndez Pelayo incluyera tempranamente a La Lozana entre las primeras continuaciones celestinescas, no entronca con tal corriente, ya que se aplican de forma estricta los criterios de Whinnom (Keith Whinnom, «El género celestinesco: origen y desarrollo», en Literatura en la época del emperador, edición de Víctor García de la Concha, Salamanca, Universidad de Salamanca, 1988, pp. 119-130) ni tampoco emparenta, siguiendo a Canet, con la comedia humanística o las secuelas de la Tragicomedia a falta de una serie de elementos (José Luis Canet Vallés, De la comedia humanística al teatro representable (Égloga de la tragicomedia de Calisto y Melibea, Penitencia de amor, Comedia Thebayda, Comedia Hipólita, Comedia Serafihna), Madrid-Sevilla-Valencia, UNED, Universidad de Valencia, 1993).

3.- Para un buen resumen, véase: Víctor Sierra Matute, «La Lozana Andaluza y el género picaresco: panorama crítico y algunos matices», Tonos Digital, 21.0 (2011). Rodríguez Mansilla la interpreta como uno de los gérmenes de la picaresca femenina que viviría su auge en el s. XVII, estableciendo así un nexo con otras obras como La pícara Justina de López de Úbeda o La Hija de Celestina de Salas Barbadillo (para estos aspectos léase, en general, su introducción a: Alon- 
a estas se suman otras más específicas: aquellas que dilucidan cuestiones de cariz gastronómico o aspectos "glotológicos» ${ }^{4}$, las que investigan el testimonio que nos deja La Lozana de una coyuntura histórica precisa ${ }^{5}$, las que entresacan las fuentes bíblicas del texto ${ }^{6}$, valoran sus cervantinas (avant la lettre) técnicas narrativas (Imperiale 1994 y Espantoso Foley 1980) o, casos más singulares y llamativos aún, las que desmantelan las huellas que El asno de oro de Apuleyo deja en la obra ${ }^{7}$, las que ponen de relieve el trasfondo morisco de un texto que acopia numerosos arabismos ${ }^{8}$ o postulan el aserto de que se trata de una novela en clave ${ }^{9}$. Al cúmulo anterior se añaden otras lecturas novedosas que han ido engrosando la panoplia, entre las que destacan las bajtinianas (Bubnova 1987), protofeministas (Fourquet-Reed 2004) o criptojudías (Costa Fontes 2005). Fácil es observar que las interpretaciones han crecido a un ritmo vertiginoso hasta alcanzar cotas impensables dos siglos atrás.

Este alud de significados indica que el problema de la condena crítica impuesta a una obra tan polivalente pudo ser durante tiempo extrínseco al texto. Más bien, consecuencia de aquella «movediza y cuestionable distinción entre lo que, en general, se dignifica y honra como erótico y lo que, en general, se aborrece y desprecia por pornográfico». ${ }^{10} \mathrm{Tal}$ vez la omnipresente «pornografía» que Menéndez Pelayo atisbó por doquier se

so Castillo Solórzano, Picaresca femenina de Alonso Castillo Solórzano: Teresa de Manzanares y La garduña de Sevilla, edición y notas de Fernando Rodríguez Mansilla, Navarra, Universidad de Navarra, 2012, pp. 11-174).

4.- Dentro de esta tendencia, se conjuga la óptica glotológica y gastronómica en: Álvaro Piquero Rodríguez, «Erotismo natural en La Lozana Andaluza: una visión traslaticia de la flora y la fauna en la obra de Francisco Delicado», eHumanista, 31 (2015), pp. 539-559.

5.- Ángela Olalla, «'Tú no has venido a Roma para soñar'. Algunas notas sobre La Lozana Andaluza», en AA.VV., Estudios sobre literatura y arte dedicados al profesor Emilio Orozco Díaz, II, Granada, Universidad de Granada, 1979, pp. 559-579.

6.- Jeromine François, «Función de la intertextualidad bíblica en el Retrato de la Lozana Andaluza de Francisco Delicado», Celestinesca, 38 (2014), pp. 37-62.

7.- El ya clásico estudio de: Juan Gil Fernández, «Apuleyo y Delicado: el influjo de El asno de oro en La Lozana Andaluza», Habis, 17 (1986), pp. 209-219.

8.- Federico Corriente, «Los arabismos de La Lozana Andaluza», Estudis Romànics, 32 (2010), pp. 51-72.

9.- Véanse los siguientes trabajos: Rosa Navarro Durán, «El Retrato de La Lozana Andaluza, una novela en clave», Beoiberística, vol. I (2017), pp. 65-80 o su libro de muy reciente fecha (La Lozana Andaluza, un retrato en clave: pasquines históricos de la Roma Babilonia, Sevilla, Renacimiento, 2018).

10.- Se cita por un estudio preliminar de José Saramago ("La Imagen y la Palabra») que encabeza la edición de: Pietro Aretino, Sonetos sobre los "XVI modos», edición y traducción de Pablo Luis Ávila, Colección Medio Maravedí, Islas Baleares, Universidad de las Islas Baleares, 1999, p. 15. Si bien se aplican a los sonetos del «Divino» y no a la obra de Delicado (aunque existan ciertas similitudes entre ambos), estas palabras resultan idóneas por cuanto se refieren a una dicotomía que también ha estigmatizado a La Lozana Andaluza durante largo tiempo dentro de nuestras fronteras. 
tornó en un sambenito que impedía que afloraran interpretaciones hechas desde otros ángulos. Pero algunas, liberadas por fin del positivismo pacato que había gobernado la crítica decimonónica y posterior, han iluminado el canto que rinde Delicado a la carne, el cuerpo o el deseo, avales de un erotismo con poderes terapéuticos que determina toda su novela. Rescatan de este modo una materia sexual en todo momento consustancial a la obra y que, como vio Allaigre (Delicado 1985: 43), ya se venía subrayando desde el inicio del Retrato con el uso de la voz "mamotreto", cuyas acepciones empleó concienzudamente el autor, no solo en base a un sentido estructural, sino eminentemente lascivo. Quizás, la laguna crítica deriva de sobreentender el erotismo como un tema obsoleto o perogrullesco, cuando aún deja mucho por elucidar.

Hoy la "normalización» de La Lozana Andaluza es palmaria ${ }^{11}$, es decir, la imagen obscena y escabrosa de esta obra poliédrica, que antaño provocó el recelo de las historias de la literatura española, ha sido enfocada con otro prisma y ya no menoscaba su carácter pionero. Aunque La Lozana sea una pieza clave de nuestra literatura desde fechas relativamente recientes, en la Roma de Clemente VII sí generó el entusiasmo de un público que a la sazón asistía a los albores de una literatura erótica (o pornográfica: la frontera es difusa) nacional, de la que los Sonetos sobre los "XVI modos» del Aretino serían uno de tantos precursores. Incidiendo en tal aspecto, dice Pablo Luis Ávila:

La literatura italiana, mucho más rica que la española hasta entonces por lo que se refiere al tratamiento de lo erótico, posee muy poca producción pornográfica previa, hasta el punto de que será Aretino, como señala en su estudio Giovanni Aquilecchia, el precursor de este tipo de literatura en el siglo XVI [...]. Simultáneamente, la difusión de la picaresca española en Italia, con el éxito de obras tan destacadas como La Lozana Andaluza o La Lena, nos muestran el interés del público italiano hacia la literatura erótica española ${ }^{12}$.

11.- Si ocasionalmente se la tilda de "rara avis» (Florencio Sevilla Arroyo, «El 'autorretrato' de Lozana en La Lozana Andaluza», EPOS, XXX (2014), p. 290) es para referirse a La Lozana Andaluza y a su fortuna literaria posterior como uno de los casos más anómalos de nuestra historia de la literatura y no por una "rareza» intrínseca al texto. El estudio de Jacques Joset da buena cuenta del rico background que subyace bajo toda La Lozana y de su plena inclusión en los cauces del humanismo italiano y, más aún, europeo del siglo xvi (Francisco Delicado, La Lozana Andaluza, edición, estudio y notas de Folke Gernert \& Jacques Joset, Madrid, Real Academia Española, 2013, pp. 353-370). A esta edición se remitirá de ahora en adelante, incluyendo el número del mamotreto en números romanos y el del capítulo en arábigas, lo cual no quiere decir que no se acceda a ediciones anteriores como la de Claude Allaigre u otras cuando sea pertinente.

12.- En el estudio de Pablo Luis Ávila («Es ojo porque te ve») que, con las palabras de Saramago, también antecede a la edición y traducción de los Sonetti Lussuriosi ya mentada (Pietro 
El erotismo del Retrato, como se ve, caló mejor en aquella Civitas Meretrix del quinientos; aunque «el tema del comercio sexual recibe un tratamiento $\tan$ directo y desenvuelto que incluso en nuestros tiempos desinhibidos logra impresionar a más de un lector», nos recuerda Tatiana Bubnova ${ }^{13}$. Delicado comparte con Bandello, Berni o el Aretino aquel realismo y unas licencias de resabios boccaccescos, pero se singulariza dentro de este cuadro genérico por impregnar la cara más risueña de la existencia y la urbe con «un dejo de tristeza y ciertos atisbos de honda melancolía»"

Delicado se presenta (y no solo en los paratextos) como un melancólico. Según recuerda la profesora Egido apoyándose en una cita de Huarte de San Juan: «todos cuantos hombres señalados en letras ha habido en el mundo dice Aristóteles que fueron melancólicos» ${ }^{15}$. El temple deviene inherente para el artista. Pero también Aldonza, en la superficie textual, actúa como un alter ego y recipiente al cual le transfiere el autor la bilis negra. Ambos saborean los frutos más dulces de la multiforme realidad; pero a la par la ponzoña. Contra la fiesta, la vida disoluta y sus loores a la carne forcejea un hiato: el Saco de Roma, el «mal francés», la Muerte. Es una realidad bifronte que ninguno consigue deslindar. Delicado es un depresivo hospitalizado, que fluctúa entre la euforia y la abulia. Tras tanta "pornografía» nadie atisbó, hasta tarde, el hondo pesar que rige el curso del texto.

Visto el estado de la cuestión, superar el problema consiste (parcialmente) en abordar, entre otros, el estudio de aquel erotismo al que queda circunscrita toda la obra sin dejarnos contaminar por consideraciones externas. Debemos ceñirnos al cuerpo de un texto (de «cuerpos» va la cosa cuando nos referimos a La Lozana) que fulge ante todo por estos ribetes eróticos, durante tiempo considerados el colmo de lo espinoso. Justipreciar la obra consiste, no en borrar el lastre "escabroso» (que también) sino en enfocarlo a) con una hermenéutica despojada de cuestiones extraliterarias, b) como tesoro en que queda quintaesenciado gran parte del valor de La Lozana y c) bajo una conciencia que, no solo por enmendar los errores críticos pasados, legitime y realce su valor per se.

A este propósito se consagran las líneas que siguen, donde se trazará una aproximación a la que es piedra angular del Retrato —el amor/el erotismo- a la lumbre de algunos antecedentes que actuaron como modelos significativos, y siempre sin soslayarse que tras el anverso del amor se esconde el reverso de la melancolía. El propósito perseguido será demostrar

Aretino, op., cit, p. 44).

13.- Tatiana Bubnova, Francisco Delicado puesto en diálogo: las claves bajtinianas de 'La Lozana Andaluza', México, Universidad Autónoma de México, 1987, p. 62.

14.- Mercedes Paglialunga de Tuma, "Erotismo y parodia social en La Lozana Andaluza», en La idea del cuerpo en las letras españolas: siglos XIII a XVII, ed., Dinko Cvitanovic, Bahía Blanca, Cuadernos del Sur, 1973, p.120.

15.- Aurora Egido, «El Persiles y la enfermedad de amor», en AA.VV., Actas del II Coloquio Internacional de Cervantistas [1989], Barcelona, Anthropos, 1991, p. 219. 
cómo el autor subvierte estos antecedentes con fines paródicos y cómo, gracias a esta lúdica pretensión y la libre designación del erotismo, la protagonista y él serenan su pesadumbre y los estragos a que aboca la sífilis.

\section{La desinhibida nominación y experiencia de la sexualidad: un analgésico}

Ante todo, nos acogeremos a esta particularidad de la que alertó Tatiana Bubnova:

Los aspectos generalmente prohibidos por la literatura "seria» y hasta cierto punto relegados al dominio de la pornografía, en La Lozana Andaluza no solo carecen de un matiz sórdido, obsesivo y "perverso», sino que están mostrados con una alegría y naturalidad tales que por lo menos invitan a reflexionar sobre un mundo mostrado totalmente bajo el ángulo de lo "obsceno". (Bubnova 1987: 62)

Delicado (más tarde se hará hincapié en ello) no rehúye la «literatura seria»: por el contrario, esta interfiere en su materia "prohibida». El reconocimiento de una escritura oficial y centralizada no como un enemigo, sino como una antípoda que invita a la fusión, es lo que termina por evitar la marginación del autor. De no ser así, Delicado hubiera echado mano de lo "perverso" o lo "sórdido" para atacar y embestir contra un sistema literario del que quedaría excluido. Para otros, la conciencia, desde los márgenes, de una escritura oficial y convencional sería sello inconfundible de ese legado popular y carnavalesco que Tatiana Bubnova ve totalmente asumido por Delicado y su obra ${ }^{16}$.

Con este juego de contrastes, se origina una disonancia que tiene mucho de chanza o alusión jocoseria. La pluma cáustica de Delicado entrevera ambos mundos adrede, con aparente ingenuidad. Eso sí, los prejuicios de raíz puritana se invalidan por sí solos puesto que el autor no nos brinda una gavilla de perversiones y obscenidades, sino un retrato de los placeres y la sexualidad conjugando en numerosas ocasiones dos caras de esta (la ideal y grotesca) con igualdad de derechos.

A veces el autor es consciente de que solo registros elevados, que se dirían propios de la literatura "oficial» de aquel momento, pueden edulcorar el degradante trasfondo de algunos mamotretos. En consecuencia, discursos de signo petrarquista o propios del amor cortés se van paulatinamente amalgamando con los lances más rufianescos. Delicado, el melancólico e infectado por las bubas del morbus gallicus, se redime del mal nombrando, deletreando y sometiendo a ritmo toda la semiótica del

16.- Mijail Bajtin, La cultura popular en la Edad Media y en el Renacimiento. El contexto de François Rabelais [1941], Madrid, Alianza, 1987, pp. 69-70. 
amor y del sexo, sin que nada le conmine. Lozana, con agudeza análoga, hace lo mismo. Aunque la mención gozosa no logre obliterar la cara oscura de la realidad que comparten ambos, por lo menos atenúa el dolor: «la melancolía decible abre el espacio de una subjetividad necesariamente heterogénea, cruelmente dividida entre los dos polos de la opacidad y el ideal, ambos presentes y necesarios ${ }^{17}$, nos dice Kristeva. Sobrevivir en tal epopeya depende de una mayor o menor detentación del saber, la oratoria y, en definitiva, de un poder que concierne tanto al ámbito público como al privado. El rey de la jauría sería el políglota (portugués, catalán, castellano, latín macarrónico: todo vale) que triunfa, con su bagaje, en una fiesta tanto real como verbal.

Como además apunta Bubnova, se trata de un libro que si ahora puede tildarse de "pornográfico» es solamente "en el sentido etimológico de la palabra, ya que se trata de la descripción de la vida de una prostituta (del griego porné, "meretriz», y graphé, "descripción»)»18. Pese a todo, ya hemos dicho que es curioso que hoy la crítica relegue en detrimento de otras lecturas esa parcela erótica hasta un plano secundario, puesto que debió considerarse desde un primer momento cuerpo y alma del Retrato, amén de que así lo declaran al lector las palabras de Delicado que anteceden al primero de los mamotretos: «Sabiendo yo que Vuestra Señoría toma placer cuando oye hablar en cosas de amor, que deleitan a todo hombre, y máxime cuando siente decir de personas que mejor se supieron dar la manera para administrar las cosas a él pertenecientes» ("Carta Dedicatoria», 5).

Como promete su autor, el erotismo será el epicentro del que arranca el «delectare». El amor, que genera placer en el lector, toma carta de naturaleza fuera y dentro del hogar de la protagonista. La cortesana "administra las cosas a él pertenecientes» (oikonomos: administración del hogar) en un estado en donde hasta en la dimensión más privada se filtra la transacción económica.

El amor se hace inherente a la vida y su curso diario. Por ello resalta Martínez Torrón:

El erotismo se respira en el ambiente de toda la narración, y se respira natural en todas las conversaciones y actos, que siempre remiten al tema. Tan generalizado, tan insistente, que se manifiesta normal, sin inhibición alguna ${ }^{19}$.

17.- Julia Kristeva, Sol negro. Depresión y melancolía [1987], Barcelona, Wunderkammer, 2017, p.117.

18.- Véase: Francisco Delicado, La Lozana Andaluza, edición de Tatiana Bubnova, Florida, Stockcero, 2008, p. XIII. Para un debate entre los términos «meretriz» o "prostituta» y su posible aplicación a la figura y el oficio de Aldonza pueden resultar de interés las palabras de: Félix Cantizano Pérez, "De las ninfas del Olimpo a las ninfas de las tasqueras: una visión de la prostitución en la España del Siglo de Oro», eHumanista, 15 (2010), p. 156.

19.- Diego Martínez Torrón, «Erotismos en La Lozana Andaluza», Espiral, 6 (1979), Madrid, Fundamentos, p. 112. 
Y algunas líneas más adelante:

En el constante doble sentido sexual, y en el jugueteo descarado y graciosamente audaz de los vocablos, las alusiones giran en torbellino siempre sobre el mismo tema, el amor. [...] Pero del amor solo se muestra la solicitación directa y abierta, por medio del doble sentido erótico que adquieren todos los actos y vocablos ${ }^{20}$.

La iteración de lo erótico, según se ve, lleva a su normalización, que no a la banalización. Delicado toma aliento para enhebrar todos los «discursos del sexo" posibles. No hay mecanismos represores, leyes o censuras que frustren su propósito. Pero la designación de lo sexual no es gratuita. Tiene un ápice de analgésico. Actúa como lenitivo contra el peso y la dureza del mundo, antes que como práctica transgresora. No hay orden contra el que sublevarse: el orden comparte la ars erótica. Delicado es hijo de un momento en donde callar, no nombrar, es síntoma de alguna coerción. Sin duda La Lozana Andaluza o los Sonetos sobre los XVI modos serían menos escabrosos que el flujo de conciencia de un autor que silenciara sus pecados o se negara a aflorar en la lengua lo que sus sentidos perciben. Unas líneas de Foucault arrojan luz sobre aquellas centurias de libertad:

Todavía a comienzos del siglo XVII era moneda corriente, se dice, cierta franqueza. Las prácticas no buscaban el secreto; las palabras se decían sin excesiva reticencia, y las cosas sin demasiado disfraz; se tenía una tolerante familiaridad con lo ilícito. Los códigos de lo grosero, de lo obsceno, de lo indecente, si se los compara con los del siglo XIX, eran muy laxos. Gestos directos, discursos sin vergüenza, transgresiones visibles, anatomías exhibidas y fácilmente entremezcladas, niños desvergonzados vagabundeando sin molestia ni escándalo entre las risas de los adultos: los cuerpos se pavoneaban ${ }^{21}$.

No obstante, Delicado prefiere tejer los «discursos» de la erótica a partir de metáforas, antífrasis y bromas para salvarse él y Aldonza, no ya de un sistema censor o inquisitorial, sino más aún de toda la pena envolvente. Para ambos, nombrar, metaforizar, traducir es vivir. No sólo se saben existentes en la cópula física, sino entonando toda la fraseología libidinosa que acompaña al acto: «El afecto depresivo - y su verbalización en la cura y las obras de arte- es la panoplia perversa del depresivo, su fuente de ambiguo placer que colma el vacío y evade a la muerte preservando

20.- Diego Martínez Torrón, art., cit, pp.112-113.

21.- Michel Foucault, Historia de la sexualidad I: la voluntad de saber [1976], Argentina-México, Ediciones Siglo XXI, 2002, p. 9. 
al sujeto del suicidio y del acceso psicótico» (Kristeva 2017: 65). Sin tal «verbalización", sobreviene la muerte.

Delicado confiere a su alter ego este modus operandi: con el esporádico periodo de hiperlucidez de los melancólicos, que alterna con instantes de atonía, Lozana nombra, frasea y expresa sus deseos, los placeres o el orgasmo, con ello superando y trascendiendo un ambiente infrahumano, zafándose de toda la miseria y la corrupción de aquel medio en que vive. Lozana y Delicado se salvan del duelo por ser conocedores de un "dominio sublimatorio»: el ritmo, la prosodia, la polivalencia (Kristeva 2017: 113). Con estos resortes se puede mentar la belleza -también- de la fealdad y lo perecedero, sin necesidad de correr un velo sobre el anverso negativo de una realidad en donde el sexo se puede nombrar y vivir en toda su entereza. Es un procedimiento teleológico por igual, donde medio y fin coinciden y son isomórficos: la estética del placer que da el placer, del erotismo de lo erótico:

Placer en la verdad del placer, placer en saberla, en exponerla, en descubrirla, en fascinarse al verla, al decirla, al cautivar y capturar a los otros con ella, al confiarla secretamente, al desenmascararla con astucia: placer específico en el discurso verdadero sobre el placer (Foucault 2002: 89).

\section{La distorsión de la forma y el fondo}

El lenguaje se subordina continuamente al sentido erógeno deseado ${ }^{22}$, se regodea en el chascarrillo, el eufemismo o los equívocos. Todos son recursos de una semiótica compartida con el lector y que dan pie a un continuo doble sentido ${ }^{23}$. En la conocida "escena de la cama», fondo y forma casan, de un modo extraño, para expresar el goce de Lozana y Rampín. Lo llamativo estriba en la concesión de una jerga caballeresca e idealista para una escena corporeizada e inferior. Usos paremiológicos, significantes ligados a las justas bélicas, la cinegética o la germanía son, a fin de cuentas, demasiada riqueza lingüística para una escena en donde el

22.- Véase la introducción de Perugini a: Francisco Delicado, La Lozana Andaluza, edición de Carla Perugini, Sevilla, Fundación José Manuel Lara, 2004, p. LVII.

23.- Lectura que llevó a cabo C. Allaigre en un indispensable trabajo de hace ya unos decenios (Claude Allaigre, Sémantique et littérature. Le 'Retrato de La Lozana Andaluza' de Francisco Delicado, Isère, Imprimerie du Nerón, 1980) o en su estudio preliminar a la edición de La Lozana que en buena parte es refundición de los postulados de aquél (Francisco Delicado, op., cit, pp. 17-155). Para tales aspectos, consúltese también un ya clásico artículo: Manuel Criado de Val, "Antífrasis y contaminaciones de sentido erótico en La Lozana Andaluza», en AA.VV., Studia Philologica. Homenaje a Dámaso Alonso, I, Madrid, Gredos, 1960, pp. 431-458. 
autor, no sin cierto voyerismo, está retratando a dos amantes sumidos en un coitus que se prolonga hasta que raya el alba.

A la par, el mamotreto muestra los alardes de elocuencia que asaltan a la protagonista en los instantes de clímax, orgasmo e hiperlucidez, y que ornan de diversión a la secuencia:

Pasico, bonico, quedico, no me ahinquéis. Andá conmigo, ipor ahí van allá! ¡Ay, qué priesa os dais, y no miráis que está otrie en pasamiento sino vos! Catá que no soy de aquellas que se quedan atrás. Esperá, vezaros he: jansí, ansí, por ahí seréis maestro! ¿Veis como va bien? Esto no sabiedes vos; pues no se os olvide. ¡Sus, dalde, maestro, enlodá, que aquí se verá el correr de esta lanza quién la quiebra! Y mirá que por mucho madrugar, no amanece más aína. En el coso te tengo, la garrocha es buena, no quiero sino vérosla tirar. Buen principio lleváis. Caminá, que la liebre está cazada. ¡Aquí va la honra! (XIV, 62).

Insertar un contenido "bajo» como este en un molde disparejo puede mover a la risa o resultar disonante. Pero la nominación de la erotología precisa aquí de este hilemorfismo distorsionado. No son necesarios los remilgos para expresar una sexualidad consustancial al hombre. Más conveniente sería una prosa sin tapujos para ahormar la nominación del deseo. Por eso, en los Diálogos del Aretino a Antonia le sacan de quicio las metáforas y los circunloquios en boca de la Enana cada vez que narra sus peripecias sexuales:

ANTONIA.- Una cosa quería advertirte y la olvidé: habla libremente y di culo, carajo, coño y hoder; que solo la sabiduría capránica puede entenderte con tanto decir cordón en el anillo, aguja en el Culiseo, puerro en el huerto, cerrojo en la puerta, llave en la cerradura, machacadera en el mortero, ruiseñor en el nido, plantón en el hoyo, lavativa en la válvula, estoque en la vaina; y así la estaca, el báculo, la zanahoria, el tití, la tal, la cual, las manzanas, las hojas del misal, el instrumento, el verbigratia, la cosa, el negocio, el cuento, el mango, la flecha, el nabo, el rábano y la mierda, no diré para tu boca, porque me gusta tener miramiento. Conque llama al pan pan, y al vino vino, y si no, guárdatelo.

ENANA.- ¿No sabes tú que la honestidad es hermosa en el burdel? 


\section{ANTONIA.- Pues sigue hablando a tu manera y no te enojes $^{24}$.}

En nuestro caso, ninguna malicia podía atribuírseles a las «cosas ridiculosas» (Digresión que cuenta el autor, 350) que Delicado estaba retratando y designando, con el verbo de por medio, para divertir a un público amigo. Antes bien, «malenconía» (Cómo se excusa el autor, 329); «malenconía» que es resultado de una "larga y prolija enfermedad» que tiene agonizando al presbítero en el hospital de Santo Jacobo de los españoles tras veintitrés años de padecimientos.

Bajo los eufemismos lozanescos no subyacen ni aberraciones ni un sexo de corte parafílico. Las «sexualidades periféricas» (Foucault 2002: 5163) — gerontofilia, presbiofilia, efebofilia, etc. — no abundan. Nada censurable existe en la agudeza y facundia con que Delicado designa lo sexual, al divertirnos con un "amor de piropos y bromas callejeras de audacia casi procaz y risa descarada. Con la insólita naturalidad de lo cotidiano ${ }^{25}$. Instantes que sí podrían espigarse como escandalosos el lector los pasa por alto entre tanto deleite. Tal es, por ejemplo, la incontinencia que asalta a Sagüeso ante la sexagenaria Divicia, con toda la gerontofilia que podría aducirse de por medio si lo abominable del asunto no se suavizara con los equívocos de los dicharacheros personajes (LIII, 261). O aquel otro pasaje en donde Lozana ofrece "jugar dos a dos» a Ulixes y Valerio, en la que hubiera sido la única escena de sexo grupal de la obra (XXX, 155) si los dos varones no huyeran corriendo al serles anunciada la llegada de Rampín. Solo así se zanja con este conato de bacanal que hubiera recordado al Satiricón de Petronio o alguna de las lúbricas andanzas de la Enana en las Sei Giornate, paradigmas de una erótica orgiástica que distan del sentido tan privado del sexo que gobierna el Retrato.

A otro título que mucho más que el nuestro tiene que ver con La Celestina, como es la Penitencia de amor (escrita en 1499, publicada en 1514) de Pedro Manuel Jiménez de Urrea, no se le arrojaron, por toda su pompa retórica o por un argumento en donde las pasiones se revisten de una mayor solemnidad, todos aquellos improperios que un eros material y prostibulario le valieron a La Lozana desde que fue exhumada en 1845. Y eso que en la obra de Jiménez de Urrea asistimos, por medio de interjecciones muy precisas, a la violación de su protagonista, la dama Finoya,

24.- Pietro Aretino, Los diálogos del Divino Pietro Aretino generalmente denominados diálogos putescos, ahora por primera vez puestos de la lengua toscana en castellano [1534], estudio, traducción, y notas de Joaquín López Barbadillo, Madrid, Akal Editor, 1978, p. 76. En semejantes eufemismos caían también las criadas de un joven Gargantúa: «Una de las ayas la llamaba mi pequeña espita; otra, mi alfiler; otra, mi rama de coral; otra, mi tapón de tonel, mi morcilla, mi berbiquí, mi taladro, mi arracada, mi diversión, mi tormento, mi colita» (François Rabelais, Gargantúa [1534], ed., de Alicia Yllera, Madrid, Cátedra, 2006, p. 119)

25.- Diego Martínez Torrón, art., cit, p. 113. 
a manos del insatisfecho Darino ${ }^{26}$. Este sí es un momento sórdido, de nuevo diluido en un lenguaje cortesano que maquilla lo abominable del acto. La acción resulta impensable entre los sanos erotismos del Retrato, impensable porque, entre otras cosas, Delicado no nos dibuja, como muy bien señaló Goytisolo, aquel arquetipo de heroína que tanto tiempo se supeditó sin rechistar a la voluntad del padre o del marido ${ }^{27}$. Otra suerte corre Polandria en la Segunda Celestina, obra casi coetánea al Retrato de Delicado. La secuela de Feliciano de Silva sí sería incluida en el índice de Valdés (1559), aun ciñéndose su protagonista a una castidad por poco inverosímil en cualquiera de las cinco linece amoris.

Entre la Penitencia de amor y nuestro Retrato hay poco más de diez años; pero corren por derroteros muy distintos. Con suerte, a autores nobles de alcurnia como Urrea la inserción en un sistema literario "oficial» les permitió granjearse la fama y salir impunes de toda condena. Para Delicado, en el exilio, el castigo fue desmedido. Aldonza vive un «materialismo fisiológico» con una desinhibición en apariencia inexistente en la obra de Rojas o algunas de sus continuaciones; materialismo hedonista, pragmático y material (Paglialunga de Tuma 1973: 122-123) que la separan de la tradición idealista. Pero no es sólo problema del erotismo: lo es de quién lo escribe; del dónde, cuándo y cómo se edifican estos «discursos del sexo", ya sea como subordinados a una reprobatio amoris o como un pasatiempo que ayuda a mitigar los estragos a que la melancolía, la sífilis y el hospital pueden arrastrar. Aldonza vocifera el placer; Finoya o Polandria el dolor y la queja.

\section{Aspecto y raigambre del eros en La Lozana Andaluza}

Así las cosas, cabe preguntarnos: ¿a qué oprobio podía sentenciarse a nuestro autor en el momento histórico del que participa? Según Imperiale, «en la Roma papal, el exiliado Delicado evoca en su prosa un mundo lleno de desenfado sexual, de voluptuosidad refinada y de erotismo refrescante», todo gracias a una lengua que «evoca cuerpos sudorosos, miradas indiscretas y actos voluptuosos ${ }^{28}$. Si bien puede ponerse en tela de juicio esa "voluptuosidad refinada", lo que está claro es que nos las habemos con una materia amorosa que se sitúa en las antípodas de la llamada

26.- La escena en concreto se encuentra en: Pedro M. Jiménez de Urrea, Penitencia de amor [1514], ed., de Domingo Ynduráin, Madrid, Akal,1996, p. 111.

27.- Se refiere, teniendo en mente a las ficciones sentimentales o La Celestina, al «prototipo de mujer objeto pasivo del placer viril, pusilánime y justamente resignada a la agresión sexual del varón» (Juan Goytisolo, "Notas sobre La Lozana Andaluza», Triunfo, XXX, n. 6891 (1976), p. 51).

28.- Louis Imperiale, «Escritura y erotismo en La Lozana Andaluza: la lengua que pega al cuerpo», La Corónica, 38.1 (Spring 2009), pp. 295, 306. 
"Venus celeste», por emplear las voces neoplatónicas al uso que irradian desde Florencia. Contraponer La Lozana Andaluza a un tratado de amor ayuda a descubrir el ejercicio subversivo que ejecuta Delicado.

Quizás sea oportuno, para comprobarlo, traer a colación unas líneas de Ficino:

Si alguno demasiado deseoso de engendrar pospone la contemplación, o busca esta generación con mujeres más allá de lo normal, o con hombres en contra del orden de la naturaleza, o prefiere la forma del cuerpo a la belleza del espíritu, aquel ciertamente hace mal uso de la dignidad del amor ${ }^{29}$.

Esta preferencia por "la forma del cuerpo» antes que por «la belleza del espíritu» (esto es, del pandemos frente al ouranios), este renegar de "la contemplación" y hacer mal uso de la que fuera "dignidad del amor»y, para más inri, esta "generación con mujeres más allá de lo normal», tal vez constituye la problemática central de todas esas «vanidades» que escribió Delicado como solaz a su enfermedad ("Cómo se excusa el autor», 328). La Lozana Andaluza se aferra a lo inferior y a lo efímero, sustrayéndose de todo afán de trascendencia o elevación platónicos.

En el Retrato asistimos a la aspiración de los personajes, apremiados por un deseo innato, la incontinencia o el ansia de "ayuntamiento" al cuerpo que constituye el objeto supremo de belleza o al favor sexual que es el Bien máximo. Pero se hace con toda la placidez y naturalidad del mundo tal como fluye (de allí el «desenfado sexual» y "erotismo refrescante» de que nos habla Imperiale). Por esta presunta inocencia Lozana y Rampín quedan impunes en el castigo moral del Saco, aun habiendo mancillado la "dignidad del amor». El sistema, que coadyuva, da el beneplácito (allí donde más acendrada se encuentra la represión, se condenó por mucho menos a la Segunda Celestina...). Deseo, antes bien, y no amor, pues el amor se siente no por la cosa ansiada sino poseída. Deseo que es

Un básico empuje propulsor, tan natural e inevitable como las otras necesidades primarias, comer, beber, dormir; algo, pues, falto de connotaciones moralísticas o religiosas, porque encuentra en sí mismo la propia justificación y absolución. El deseo no es tentación que lleva a la condenación: es el resorte vital, que nunca encuentra su satisfacción definitiva, ya que, fisiológicamente, tiene que volver a presentarse ${ }^{30}$.

29.- Marsilio Ficino, De amore: comentario a «El Banquete» de Platón [1594], traducción y estudio preliminar de Rocío de la Villa Ardura, Madrid, Tecnos, 1989, p. 40.

30.- En la introducción de Perugini: Francisco Delicado, op., cit, pp. XLI-XLII. 
En la platónica distinción entre el cuerpo y el alma Delicado opta por cantar los goces y los placeres de la carne. Incluso cuando los personajes parecen ahondar en introspecciones o lamentos de signo petrarquista, bajo la aparente espiritualidad se leen intereses diametralmente opuestos. Los fastos culinarios son un aliciente para la voluptuosidad, y si bien la suma de gula y lujuria es tan antigua como el amor y el hambre, nadie la exacerba tanto como Delicado ${ }^{31}$. La cuestión es: ¿tal elección por el materialismo es un subterfugio? Unas últimas palabras parecen admonitorias respecto a este punto:

El ánima del hombre desea que el cuerpo le fuese par perpetuamente; por tanto, todas aquellas personas que se retraerán de caer en semejantes cosas, como estas que en este retrato son contadas, serán pares al espíritu, y no a la voluntad ni a los vicios corporales... (El ánima del hombre, 331).

Aunque serían "pares al espíritu» quienes se abstuvieran de los «vicios corporales», tal aspiración se invalida en La Lozana. El ascensus a la purificación se frustra por la cárcel del cuerpo y sus instintos. Nadie se zafa de las pulsiones de una erótica concupiscente que se asienta en lo terreno y que, con ello, más se ceba cuanto más se materializa. Acontece un perpetuo disfrute de una sexualidad que, al nombrarse, se redescubre y se reivindica a sí misma. El placer prima y, como señala Fourquet-Reed, el realismo grotesco de La Lozana «materializa sistemáticamente todo lo que pertenece al mundo espiritual y abstracto» con un "movimiento hedonista, que se concentra en el hombre en sí mismo como individuo y en su propio cuerpo con todos sus poderes de sensualidad y erotismo $»^{32}$.

De todas formas, Delicado parece consciente de la «vanidad» de tantos amores terrenales. Como solución que destaparía el didactismo en los momentos postreros, fuerza a Lozana a cantar la palinodia en pos del amor $D e i^{33}$. Por consiguiente, las andanzas juveniles de Aldonza habrían servido como exemplum que habría de entenderse en sentido inverso. Sobre tantos escarceos y encontronazos entre hombres y mujeres planearía una reprobatio y así el retrato pintado por Delicado pasaría a formar parte

31.- Piénsese, por ejemplo, en la Comedia Tinellaria de Torres Naharro o en algunas escenas de la Segunda Celestina en donde la francachela alterna con desnudos y venalidades (cena XXXIV en: Feliciano de Silva, Segunda Celestina [1534], edición de Consolación Baranda, Madrid, Cátedra, 1988, pp. 478-506).

32.- Linnette Fourquet-Reed, Protofeminismo, erotismo y comida en La Lozana Andaluza, Maryland, Scripta Humanística, 2004, pp. 89-90.

33.- Solución que se extrae de: José A. Hernández Ortiz, La génesis artística de 'La Lozana Andaluza': el realismo literario de Francisco Delicado, Madrid, Ricardo Aguilera, 1974, p. 38. La hipótesis de este estudioso, ya clásica, le convierte aún hoy en el adalid de las tesis del moralismo y realismo intencionales del Retrato. 
de una larga tradición de censuras contra el amor corporal, material y terreno que tendría en el libro III del De arte honeste amandi de Capellanus un notable antecedente.

El advenimiento del Saco supondría el cese del verbo y de los discursos del sexo, el regreso del autor y de una decrépita protagonista a la afasia y la abulia melancólica. Roma muere cuando la sexualidad ya no puede nombrarse, y con ella todos quienes han articulado (porque detentaban el poder y el saber) los signos del sexo. Muerta Roma, según el palíndromo, moriría el Amor. Tan sólida es la relación entre el microcosmos-Lozana y el macrocosmos de la urbe que la destrucción de una implica la destrucción (cuando menos, simbólica) de la otra.

La libertad, antes del final, era rotunda; invitaba, sin trabas, al amor frui. También la celeridad y facilidad con que los favores se ganan si lo permite el caudal económico del que busca servirse de alcahuetas o beneficiarse del favor sexual de las hetairas. Satisfacer los instintos cuanto antes es solución tan rudimentaria como terapéutica: en el sexo y en su mera nominación se anulan los vértigos del melancólico-depresivo, se calma el dolor más lancinante y se libera la superabundancia seminal. Lejos del psicoanálisis, tal terapia emparenta con la obra práctica de médicos del s. XIII como Gordonio ${ }^{34}$. La cura se procura, si más rápido, mejor: una erotización suple a una pérdida, un placer arrostra consigo un dolor (Lozana, perdido su caro Diomedes, disfruta junto al efebo Rampín).

Aunque el «mal francés» y la muerte sobrevuelan a cada cópula (Imperiale 2009: 296), un deseo instintivo, ajeno a ellos, es el que imanta el encuentro sin tener en cuenta los óbices. En estos lances eróticos, la elocuencia significa poder, dominación. Domeñar los códigos de la sexualidad incrementa la dicha. En el mamotreto XIV, Lozana adentra al no tan neófito Rampín, que permanece callado, en una suerte de rito iniciático donde las palabras y la voz están por encima del tacto o el gusto. La sexualidad no admite ambages y se desase de una entorpecedora moral tan sacralizada antaño.

Con razón señalaba Wardropper en un artículo ya clásico:

En la novela de Delicado, el acto amoroso no tiene preludios; los favores extremos se conceden siempre con solo que se pidan. Las mujeres se muestran siempre tan dispuestas a la conquista amorosa como los hombres. [...] El centro de este código sin rodeos del amor es el

34.- Bernardo Gordonio, Lilio de medicina: un manual básico de medicina medieval, edición de Brian Dutton y John T. Cull, Madison, Hispanic Seminary of Medieval Studies, 1991. Para el tema de la enfermedad de amor también pueden ser de grata lectura e interés las páginas de: Pedro M. Cátedra, Amor y pedagogía en la Edad Media: estudios sobre doctrina amorosa y práctica literaria, Salamanca, Universidad de Salamanca, 1989, pp. 57-84 o las palabras que dedica al tema Ioan P. Culianu, Eros y magia en el Renacimiento: 1484 [1984], Madrid, Ediciones Siruela, 1999, pp. 47-49. 
acto sexual, no los actos precedentes, concomitantes o subsiguientes ${ }^{35}$.

Bajo tal concepción, al Retrato se le ajustaría mejor aquella definición, algo más taimada y minada de ecos ovidianos, que del amor diera unos siglos antes Andrés el Capellán:
Amor est passio quaedam innata procedens ex visione et immoderata cogitatione formae alterius sexus, ob quam aliquis super omnia cupis alterius potiri amplexibus et omnia de utriusque voluntate in ipsius amplexu amoris praecepta compleri ${ }^{36}$.

A la novela de Delicado le es ajena la concepción erotológica que los diálogos de Ficino, Castiglione, Bembo o Hebreo pregonarían pocos decenios más tarde. Es un amor jovial y retozón, no contemplativo. Amor de vientres y nalgas, de cuerpos y formas que seducen. Amor que hasta la misma fealdad y suciedad alimentan. Si no, ¿̇cómo logra Delicado retratarnos el atractivo de una mujer sifilítica y sin nariz, que pasea una espantosa estrella en la frente y que sufre los achaques de la edad sin por ello dejar de suscitar el deseo de todos aquellos haraganes que la rodean? Hasta el último día, la semblanza de Lozana recibe toda clase de requiebros ${ }^{37}$. Al criado Nicolete le asalta, de hecho, un irrestañable deseo al contemplar el cuerpo de Lozana, ya mayor, paseando por la calle. Por ello la posee sin más dilación y sin circunloquios, hasta el clímax de un orgasmo precipitado:

LOZANA.- ¡Nicolete, hijo mío! ¿Qué haces?

NICOLETE.- Soy de guardia. ¡Y mirá, Lozana, qué pedazo de caramillo que tengo!

LOZANA.- ¡Ay, triste! ¿Y estás loco? ¡Está quedo, beodo, que nos oirán!

35.- Bruce Wardropper, "La novela como retrato: el arte de Francisco Delicado», Nueva revista de Filología Hispánica, VII (1953), p. 481.

36.- Andrés el Capellán, De amore. Tratado sobre el amor, edición y traducción de Inés Creixell Vidal, Barcelona, Quadras, El festín de Esopo, 1985, pp. 54-55.

37.- Así, Silvano la requiebra del siguiente modo: «Dios os bendiga, qué gorda estás» (XLIII, 220). E incluso las mismas mujeres, como ya la madre de Rampín lo había hecho antes, la prodigan en continuos elogios, tales como los de Leonor: «iAy, que gorda está esta putana! Bien parece que come y bebe y triunfa, y tiene quien la cabalgue para el otro mundon. (XLVIII, 240). Se subraya el adjetivo que, lejos de ser despectivo, resulta toda una alabanza con la que los interlocutores reconocen la prodigalidad de bienes de Lozana a lo largo de las diferentes etapas de su vida. Al hilo de lo dicho, el vientre y las tripas constituyen un nexo con el grotesco y la cultura carnavalesca de la obra: "Así, dentro de la idea de las tripas el grotesco anuda indisolublemente la vida, la muerte, el nacimiento, las necesidades naturales y el alimento: es el centro de la topografía corporal en la que lo alto y lo bajo son elementos permutables» (Mijail Bajtin, op., cit, p. 147) 
NICOLETE.- Callá, que todos están arriba. Sacá los calzones, que yo os daré unos nuevos de raso encarnado.

LOZANA.- Haz a placer, que vengo cansada, que otro que calzones quiero.

NICOLETE.- ¿Qué, mi vida, de cara arriba?

LOZANA.- Yo te lo diré después.

NICOLETE.- ¡No, sino agora; no, sino agora; no, sino agora! (LX, 302)

En el artículo ya mentado, Wardropper sentenciaba que el eros de $\mathrm{La}$ Lozana Andaluza no era "el amor cortesano de la Cárcel de amor, ni la idea neoplatónica de la Diana, ni siquiera el concepto ovidiano del Libro de buen amor, que es el que más se le parece» (Wardropper 1953: 481). Nos interesa aquí ver cómo el crítico tampoco esquivó el eco de Ovidio y de su obra. En efecto, por criterios biográficos no pudo afectarle a Delicado el neoplatonismo de La Diana; pero sí un considerable influjo "ovidiano» que en España ya se había hecho notar con el libro del Arcipreste de Hita y consolidado con la traducción catalana del De amore de Capellanus y la novelística sentimental del XV aún en boga. Quizás, dentro del bagaje filográfico del autor, Ovidio sería el último de los posos por examinar, una incursión a la que hasta ahora la crítica no se ha aventurado.

La postura a que instiga el vate latino a los acólitos de Venus es taimada como ninguna otra. Por esta misma razón, las analogías que pudieran señalarse con respecto a la postura del amor en La Lozana no serían del todo disparatadas. Las reglas ovidianas se saben, como ya venía sucediendo en la novela sentimental, poco efectivas, y si se remite a ellas las más de las veces es de una forma paródica, para así descubrir la lejanía que media entre la teoría del consejo y su puesta en praxis. Aunque el espacio sea breve, no se cerrará el epígrafe sin apuntar antes ciertas concomitancias.

Veamos: por lo pronto, Ovidio ya se refería en los Amores a ese arquetipo de mujer-alcahueta que se sirve de la elocuencia, como Lozana, para alcanzar sus reprobables metas («se ha propuesto ultrajar los tálamos honestos/ y, con todo, a su lengua perniciosa/ no le falta elocuencia», I, VIII, 171 ${ }^{38}$. Más adelante, los vituperios contra los afeites y tintes son abundantes (I, XIV, 201-204), y podrían estudiarse a la luz de todas aquellas cortesanas que son «remendadas» por Lozana para disimular ciertos achaques de la vejez y la sífilis. Prosigue Ovidio en Amores (II, II, 216) aludiendo a aquellos criados (verbigracia, Rampín) que se ven favorecidos

38.- A partir de ahora se cita por la edición conjunta de González Iglesias: Ovidio, Amores/ Arte de amar, edición de Juan Antonio González Iglesias, Madrid, Cátedra, 1993, indicando el número de libro y de capítulo en números romanos o el número de la(s) página(s) de la edición en arábigas. 
al ser los enamorados de sus señoras (Lozana) ${ }^{39}$ o al arquetipo de mozo (Amores, II, XIX, 281-285) que tolera la infidelidad como conditio sine qua non para poder preservar el amor. Asimismo, los paralelismos no terminan en este punto.

Así como en el Arte de amar (I, 367-390) exhorta el vate a los amantes a buscar a Cupido en templos, pórticos, foros o teatros, tornándose la ciudad en el espacio idóneo para acoger una "danza general del eros», también la urbanitas rige el amor lozanesco. En la estufa, lugar parecido al balneario aconsejado por Ovidio, Lozana y Rampín viven una escena de depilaciones, desnudos y voyerismo (ya hemos aducido con Foucault que hasta el s. XVII los cuerpos tenían otra forma de pavonearse, desnudarse, exhibirse ${ }^{40}$ ). El poeta latino instiga al amante a servirse de las falsas promesas siempre que sea necesario (I, 419-421), ruin estratagema que personajes como Diomedes o Trujillo practican para ganar la aquiescencia de Lozana. Paralelamente, el pasaje "Debe el hombre tomar la iniciativa» (I, 425-426) se acopla perfectamente a ese primer encuentro entre Aldonza y su "caro amante» Diomedes, así como el que recibe por título «Cómo en la cópula actuará el varón» (II, 488-490) parece representarnos a Rampín en los numerosos asaltos sexuales del mamotreto XIV. Los consejos para el disfrute del momento ("Aprovechad el tiempo, disfrutad», III, 498-501) no de otro modo resuenan en la filosofía "carpetiana» que fluye de forma subrepticia bajo la Roma de Delicado (Fourquet-Reed 2004: 12-19) y los apuntes sobre "La higiene femenina y los cosméticos» (III, 507, 509) o el «Arte de pronunciar, andar y bailar» (III, 515-516) parecen formar parte del vademécum rutinario de Lozana. La exploración más detenida de todos estos no sería superflua si el corto espacio no lo impidiera de momento ${ }^{41}$.

\section{Los mamotretos III, IV, XII y LV}

La experiencia erótica del Retrato, como se ha puesto de relieve, se colma y sacia sin excesivas dificultades. Las trabas atañen más bien al poder adquisitivo, así como al "griñimón» o la muerte (Imperiale 2009: 296) que, junto al Saco, son la tríada de males pestíferos de la Roma putana. Son

39.- Este aspecto en concreto también parece captar la atención de Claude Allaigre en su introducción a la edición de La Lozana Andaluza (Francisco Delicado, op., cit, pp. 34-40).

40.- Obsérvense, por ejemplo, estos versos: «Rapándoselo estaba cierta hermosa/ hasta el ombligo toda arremangada/ las piernas muy abiertas, y asentada/ en una silla ancha y espaciosa» (Pierre Alzieu, Robert Jammes \& Yvan Lissorgues, Poesía erótica del Siglo de Oro, Barcelona, Crítica, 1984, p. 52).

41.- Para los remedios contra el paso del tiempo, los achaques de la edad o el «mal de Nápoles» que turbaron a aquella sociedad tan hedonista, véase: Linnette Fourquet-Reed, op., cit, pp. 92-93. 
factores ínsitos a esa urbe venal y del lenocinio. Y, a la par, consecuencia de esa bajada del empíreo idealista al mundo social y del incipiente capitalismo que ya preludiara Rojas. Pero entre la desgracia y el ambiente infrahumano Delicado abre un festivo espacio en donde cohabitan la parodia, la ironía y la risa. La broma requiere de esta frontera para combatir al «terror cósmico» (Bajtín 1987:302).

Solo existen una serie de mecanismos que dificultan el plácido itinerario que sigue el eros. Y, precisamente, bajo su mención se esconde un juego de intertextualidades. Los reveses de la Fortuna, una monogamia difícil de conservar, la despótica voluntad del padre o la separación de los amantes que, rompiendo el canon de la novela clásica, no se reencuentran jamás, son buenos ejemplos de los motivos escogidos por el autor para ser sometidos a escarnio. La gran mayoría tienen una génesis dramática o novelística y, a tal efecto, eclosionan en la parte más narrativa de la obra (esencialmente, al inicio). Actúan como un claro guiño a los amores trágicos y sometidos a los reveses de la suerte que determinaron la novela griega y bizantina, pero que también impactaron en las ficciones sentimentales de la Baja Edad Media o en La Celestina. Los mamotretos III y IV son ejemplos de meridiana ejemplaridad. Ambos abundan en reminiscencias "serias» y casi tópicas de aquellas producciones prosísticas que son aprovechadas por Delicado con unos claros fines paródicos ${ }^{42}$.

Por tal motivo, y no sin cierta ironía y malicia, Lozana no duda en su primer encuentro con Diomedes ${ }^{43}$ en declarar su service amoureux ( $Y$ Yo me llamo Aldonza, a servicio y mandado de vuestra Merced», III, 18). Luego plañe graciosamente los daños que le han causado las saetas disparadas por un «mochacho» bajo el cual se oculta ese Cupido al que los trovadores, los stilnovisti o toda la poesía cancioneril española profirieron tantas quejas que casi resultan obsoletas en tiempos de Delicado. Irónico resulta también que la flecha dorada por la que se ve asaetada Lozana en la "teta izquierda»"4 sea la que en la Antigüedad hechizaba a los amantes a la correspondencia. Porque, más tarde, su "caro Diomedes» resulta ser un proxeneta que la prostituye por todo el Levante y que disfruta de una forma un tanto voyerista con las miradas lujuriosas que sus amigos lanzan a Aldonza. Delicado no ceja en su mordacidad y, poco después, torna a Diomedes en un émulo de Calisto: aguijoneado por la oggritudo amoris, el mercader reclama el soco-

\section{2.- Tatiana Bubnoba, op., cit, pp. 102, 162-167.}

43.- Para Allaigre, de hecho, este pasaje en concreto constituye una «escena francamente caricaturesca» que juega con los tan manidos «tópicos del amor cortés, que ya se las habían visto con el yunque celestinesco» (en su introducción a: Francisco Delicado, op., cit, p. 101).

44.- «En la teta izquierda me tocó» son las seis palabras que, a juicio de Wardropper, desinflan toda la "pompa retórica» de esta escena que, como también había subrayado Allaigre, se configura como una maliciosa parodia de los «amores novelescos convencionales» (Bruce Wardropper, art., cit, p. 482.) 
rro de remedia y de galenos para sanar su patología, «Señora, si no remediamos con socorro de médicos sabios, dudo la sanidad» (III, 19).

Las irónicas quejas del raveñano a Diana, divinidad casta por antonomasia, son por otro lado de un cinismo sin parangón por cuanto las tañe alguien que impele a su amante a la poligamia. Pero Lozana no para mientes en lo ignominioso de la venalidad. Anda alelada con la belleza de Diomedes, a quien la Naturaleza ha colmado de una hermosura seráfica (por un motivo parecido Calisto se había obnubilado con Melibea): «Le parecía a ella que la natura no se había reservado nada que en su caro amante no hubiese puesto» (IV, 22). Otro homenaje burlesco a la ficción sentimental puede ser la intrusión en escena del padre de Diomedes, quien gesta la tragedia postrera y maquina el asesinato de Aldonza. Con ello se separan los dos amantes que habían unido "due anime in uno core» (III, 19), verso con el que Delicado parodia otro motivo más: la transformación del amante en el amado ${ }^{45}$.

Ambos, para más inri, ya habían tenido hijos, tras prometerse en un matrimonio que se configura como la monógama salvación moral; pero que aquí es, no solo alusión sarcástica a aquellos desposorios de las fábulas sentimentales, sino preanuncio de la catástrofe venidera. El encratismo hubiera sido solución más atinada ${ }^{46}$. La mención a ciertos tratadistas erotológicos no es en absoluto disparatada aquí, y más si meditamos que el encontronazo, urdido por la tía de esta, entre Lozana y Diomedes transgrede una máxima a cuyo cumplimiento alentaba Capellanus a los amantes:

Primitus ipsam suo more salutet; sed haec sunt generaliter dicenda et omni credantur amanti, ut post salutationem non statim a verbis amoris incipiant, quia pellicibus talia sunt initia facienda... ${ }^{47}$

Por contraposición, Lozana y Diomedes no hacen más que hablar del amor y de sus efectos en esta primera plática, invirtiendo la sentencia del Capellán. Tal materia conversacional solo quedaba justificada cuando la charla se entablaba con una "prostituta». Pero aquí no es así si nos atenemos al hecho de que Lozana no es todavía cortesana, por cuanto este lan-

45.- Próximo al tópico del anima est ubi amat, la paráfrasis abunda en intertextualidades: para Paglialunga de Tuma (art., cit, p. 124) y Tatiana Bubnova (op., cit, p. 165) sería reminiscencia de un verso de Dante, mientras que para Gernert se extrae de las Sei Giornate (Folke Gernert, Francisco Delicado Retrato de la Lozana Andaluza und Pietro Aretinos Sei Giornate. Zum literarischen Diskurs über die käufliche Liebe im frühen Cinquecento, Ginebra, Droz, 1999, p. 48) y para Carla Perugini, echando mano de fuentes más antiguas, procede indudablemente de la Ética Eudemia de Aristóteles o del Banquete platónico (ver notas a su edición: Francisco Delicado, op., cit, p. 24)

46.- Para una síntesis del concepto «encratismo», consúltese: Ioan P. Culianu, op., cit, pp. 42-43.

47.- «En primer lugar salúdele según la costumbre; pero lo que generalmente hay que decir -y esto todo amante lo tenga por seguro- es que no hay que empezar a hablar del amor inmediatamente después del saludo, pues un inicio tal solo procede con las prostitutas» (Andrés el Capellán, op., cit, pp. 74-75) 
ce tiene lugar en su prehistoria andaluza y anterior a la llegada a Roma. La transgresión vuelve a materializarse cuando ella y Rampín viven su primera toma de contacto y el mozo inquiere con intenciones sexuales: «Decime vos, ¿̇dónde dormiré esta noche?» (XII, 46). Viejos preceptos y loci communi de la erótica se tergiversan, pues el autor se permite «saltarse a la torera los cánones del amor cortés» (Imperiale 2009: 305) o aludir con sarcasmo a la vía matrimonial cuando, ya adentrada en años, Lozana llama a Rampín su «pretérito criado» (LXVI, 318), «pretérito» porque en las postrimerías de la historia ya es su marido.

En estos instantes de alborozo, la pena se abre camino e irrumpe entre tanto júbilo. Lozana se torna en sujeto melancólico o depresivo tras el abandono de Diomedes. Una «tristeza inconsolable oculta a menudo una predisposición a la desesperación», nos explica Kristeva ${ }^{48}$. De ahí los numerosos golpes contra una roca con que se aturde Lozana, después de un naufragio que casi acaba con su vida. El raveñano será evocado siempre como parte de un pasado glorioso e irrepetible, bajo el topoi manriqueño del tiempo pretérito=mejor; pero también como Objeto o Cosa perdida, al cual aureola una paradójica erótica de amor-odio que ata y desata cada vez que es evocado. De los hijos procreados, no se sabrá nada nunca más. Diomedes quedará introyectado en el "yo» y en la memoria de Aldonza como un amado-odiado. Esto puede acarrear — desde el psicoanálisisuna ambivalencia del sujeto afectado respecto al objeto perdido que es causa de su duelo (Kristeva 2017: 25):

La pérdida del objeto erótico (infidelidad o abandono del amante o del marido, divorcio, etc.) es sentida por una mujer como un ataque contra su genitalidad y equivale, desde este punto de vista, a una castración [...] La pérdida exterior es inmediata y depresivamente vivida como vacío interior ${ }^{49}$.

Con todo, la experiencia traumática se resuelve gracias a un método al que Kristeva denomina el "curso anodino». Se trata de una actividad febril, que en nuestro caso desarrolla Lozana como buhonera de cosméticos, vendedora de alimentos, sanadora del «mal de madre» y celestina, medianera o tercera cuyos favores ofrece a cambio de bienes materiales ${ }^{50}$. Lozana se salva así de la "pulsión de muerte». Pero la solución no menoscaba la tristeza de la protagonista y su creador: «el ser hablante, desde su

48.- Julia Kristeva, op., cit, p. 49.

49.- Julia Kristeva, op., cit, p. 99.

50.- El «curso anodino» es, para Kristeva, la segunda alternativa que tiene la mujer melancólica que sufre una depresión, y que esquiva las embestidas de un «Ello» terrible con una actividad incesante y sin pausa. La primera sería el "curso mortífero", que aquí no acontece porque Diomedes, en efecto, no vuelve a aparecer en la trama, ni tampoco parece su vieja esposa Lozana dispuesta a ninguna clase de venganza contra él (Julia Kristeva, op., cit, p. 100). 
capacidad de perdurar en el tiempo hasta sus construcciones entusiastas, sabias o simplemente divertidas, exige en su base una ruptura, un abandono, un malestar» (Kristeva 2017: 59).

Otras secuencias «divertidas», que son reminiscencias jocosas de viejas novelas o tratados amorosos, se repiten en adelante. El mamotreto LV acopia numerosas chanzas ${ }^{51}$. Lozana le aconseja sus remedia amoris al joven Coridón, nombre este último que en líneas onomásticas ya remite con malicia al universo idílico de las Bucólicas de Virgilio y, peor todavía en el contexto lozanesco, a la falta de priapismo del que recibe tal nom$b^{5}{ }^{52}$. El joven, según cuenta, languidece por el mal de amores. Lozana parafrasea por primera vez a Virgilio: omnia vincit amor (Bucólicas, X, 69). A modo de glosa le recuerda a Coridón: «no solamente el Amor es mal que atormenta a criaturas racionales, mas a las bestias priva de sí mismas» (LV, 270). Con esta verdad apodíctica Lozana vuelve a parafrasear, casual o causalmente, una tirada de versos ahora pertenecientes a las Geórgicas ${ }^{53}$, y que ya eran todo un lugar común acerca de la omnipotencia y el poder omnímodo del Amor.

La aegritudo amoris que aqueja a Coridón le hace "hervir la sangre» y estar "consumido", efectos psicosomáticos que remiten a los tratados de la medicina práctica que había observado los cuadros clínicos del «amor hereos». En esta vertiente, Gordonio y su Lilium Medicinale habían sido conspicuos representantes, con una sarta de etiologías, causas y curas para los enfermos de amor. Lozana saca a relucir un remedio con mejoras terapéuticas en los incontinentes: la cópula indiscriminada ${ }^{54}$. Ella misma había exhortado anteriormente: "Y otros que piensan que por cesar han de vivir más, y es al contrario, que semel in setimana no hizo mal a nadie» (XXXVIII, 197).

Lozana diagnostica a Coridón su «amor hereos» y para su explicación se sirve del ejemplo de un gato "que ni come, ni bebe, ni tiene reposo" (LV, 270). Con esta parábola alude a una parte importante de aquellos efectos psicofísicos que consumían a los enamorados, nobles y jóvenes, afectados por la enfermedad, ya algo tópicos a la sazón. Pero Delicado, he aquí la sorna, inocula estos lugares comunes en un graciosísimo

51.- De hecho, para Bubnova son estos últimos mamotretos aquellos que se caracterizan, en el plano textual, por la «inversión paródica de un género discursivo serio» (Tatiana Bubnova, op., cit, pp. 164-167)

52.- Como curiosidad que refuerza el guiño, Coridón se declara oriundo de Mantua, patria del vate latino.

53.- En concreto, los vv. 241-243: «omne adeo genus in terris hominumque ferarumque et genus aequoreum, pecudes pictaeque uolucres, in furias ignemque ruunt: amor ómnibus idem» (Virgilio, Geórgicas, edición de Jaime Velázquez, Madrid, Cátedra, 1994, p. 194).

54.- Un buen acercamiento a todos estos temas en nuestra obra se encuentra en: Emily Kuffner, "En el tocar está la virtud': The Eros of healing in La Lozana Andaluza», La Corónica, 45.1 (2016), pp. 63-87. 
correlato gatuno, y se los aplica cual analgésico a Coridón, un reo de la melancolía como lo son Lozana o el autor. Nuestra protagonista, a fin de cuentas, es conocedora de todo lo relativo al Eros, de lo cual nos había informado el Caballero antes: "es muy universal (quiere decir docta) en todas las otras cosas que para esto de amores se requiere» (XXXVI, 182).

Como vemos, la philosophice amoris (si voz tan seria puede traerse a colación aquî) del Retrato se apoya con frecuencia en la burla. Tal vez la más mortífera de todas había sido la disparada en torno al motivo de la visio o la «visión de amor $»^{55}$. Desde los diálogos platónicos y Petrarca el objeto de la mirada era la suma belleza y el Bien; pero al decir de Lozana: «los ojos de las mujeres se hicieron de la bragueta del hombre» (XLII, 213). Por metonimia, la bragueta se convierte en un erómeno.

Precisamente por vía de la visio Coridón se enamoró de una dama prometida en matrimonio con otro. Este nos relata el primer saetazo recibido en un registro y tono elevados, recordándonos no ya al modo en que se enamoraron por los ojos, de buenas a primeras, tantos galanes y damas en las ficciones sentimentales o novelle italianas, sino a la retórica ampulosa con que solía darse noticia de ello. La Historia de duobus amantibus, de Eneas Silvio, sirve de ilustración a lo antedicho: su protagonista Euríalo se enamora así de Lucrecia y ejecuta las más ridículas estrategias para luego adentrarse en la casa de su amada, estrategias nada disímiles de las llevadas a cabo por Coridón (Lozana le aconseja vestirse de mujer) para realizar una incursión al hogar de su querida. Para más intríngulis, el uso de los disfraces afeminados de Coridón subvierte otra de las reglas a cuyo cumplimiento, según Capellanus, era obligado el amante en aras de preservar el amor:

Praeterea quisque placibilis debet ese ornatu amanti et suam moderate colere formam, quia corporis immoderata cultura taediosa cunctis exsistit et naturalis inde sequitur contemptio forma $e^{56}$.

\section{El abismo entre la teoría y la praxis: la génesis de lo risible}

Delicado, según se ha subrayado, adorna los amores de La Lozana con un rico juego de intertextualidades. La ironía, el cinismo y la parodia no dejan de ser un solaz con los que el autor combate la melancolía. Podría esgrimirse un ejemplo más, acontecido no mucho antes:

55.- Primera de las quinque lineae amoris: visus, allocutio, tactus, basium, coitus.

56.- «Por otro lado, tiene que agradar a su amada en el vestir y cuidar con moderación su aspecto, pues el cuidado excesivo del cuerpo molesta a todos y provoca el desprecio de la belleza natural» (Andrés el Capellán, op., cit, pp. 289-291). 
CAPITÁN.- Señora Lozana, ¿cuántos años puede ser una mujer puta?

LOZANA.- Dende doce hasta cuarenta.

CAPITÁN.- ¿Veinte y ocho años?

LOZANA.- Señor, sí: hartarse hasta reventar... (XL, 202).

Lozana alude al precoz umbral de los doce años como la edad idónea para que la hetaira se inicie en su oficio, y a los cuarenta como el momento exacto para retirarse y obtener la tan soñada «taberna meritoria». En referencia a la quaestio "¿Qué personas son aptas para amar?», casualmente había escrito Capellanus: "Similiter ante duodecim annos femina et ante decimum quartum annum masculus non solet in amores exercitu militare ${ }^{57}$. ¿Coincidencia fortuita? ¿O más bien guiño intencionado? Delicado se nos revela conocedor, si no del De arte honeste amandi de Capellanus, sí de un lugar común para todo «bachiller» que fijaba en los doce años el momento de ingreso de la mujer en las milicias de Cupido por cuestiones que, antes bien, concernían a la fertilidad biológica.

Delicado también discurre, en otra ocasión, sobre la edad de la pérdida de la virginidad. A una pueril Aldonza se le "derrama» aquella "sangre que del natural tenía» a la edad de once años, en Granada, (II, 14). Al año siguiente, pasa a formar parte de las huestes de Venus, cumplidos los doce años que sugería como idóneos el Capellán ${ }^{58}$. Esta precocidad, violenta a todas luces, cumple milimétricamente con las preceptivas de los tratados. Por el contrario, Rampín tiene solamente diez años cuando protagoniza el libidinoso mamotreto XIV, una promiscuidad inaudita del mozo que a menudo se pasa por alto. De ello nos había advertido su madre: «De diez años le sacamos los bracicos» (XII, 46). Cuatro años antes de la edad recomendada por Capellanus para el varón no es poco; pero el lapso origina un vestigio - la efebofilia - de esa "sexualidad periférica» a la que aludía Foucault, por cuanto Lozana es una mujer casada que perpetra el adulterio con unos cuantos años de más que el mozo. Todas estas transgresiones se supeditarían, según se ha visto ya, a una intención paródica, y aunque puedan llegar a parecer inverosímiles el propósito perseguido es muy otro.

57.- «Del mismo modo la mujer no suele ingresar en el ejército del amor antes de los doce años ni el hombre antes de los catorce» (Andrés el Capellán, op., cit, pp. 66-67).

58.- Y esos cálculos cronológicos ejecuta, también, Allaigre, aunque de la intertextualidad con un tratado como el de Andreas Capellanus no mencione nada (Francisco Delicado, op., cit, p. 90). Una franja de edad semejante puede contemplarse en otro jalón importante dentro de la corriente celestinesca, como es La hija de Celestina. La astuta Elena da cuenta de lo siguiente: "como mi madre se resolviese a abrir tienda — que al fin se determinó antes que yo cumpliese los catorce de mi edad - no hubo quien no quisiese alcanzar un bocado» (Alonso Jerónimo de Salas Barbadillo, La hija de Celestina [1612], edición de Enrique García Santo-Tomás, Madrid, Cátedra, 2008, pp. 112-113) 
Lo común a otros ejemplos ya espigados, como los de Diomedes o Coridón, estriba en la enorme distancia que se abre y existe entre los postulados teóricos a los que remite la intertextualidad y los actos que llevan a cabo los personajes en la secuencia. En esta disonancia se cifra el elemento risible del Retrato. De ello ya se percató bien Bubnova:

Visto desde este ángulo, el Retrato ya desde la primera página debía de "provocar a risa», y no tanto por lo risible del personaje como por la manera misma de presentarlo, por el contraste que surgía de la mezcla de un contenido «bajo» a una forma destinada tradicionalmente a otros propósitos mucho más elevados y, sobre todo, serios. Se trata de una inversión paródica de un género discursivo... (Bubnova 1987: 163-164)

Los personajes profieren parlamentos solemnes sirviéndose de un estilo muy elevado, pero en realidad nos relatan escarceos sexuales de muy distinto signo, que podrían tildarse perfectamente de "ovidianos». De hecho, algunas novelitas sentimentales, contaminadas de "ovidianismo", ya habían llevado a cabo procedimientos muy parecidos, en los que se volvía a cifrar toda la gracia. Quizás poner sobre coturnos los actos más infames es otro ardid para superar la cruda realidad. A propósito de Arnalte, el protagonista del Tractado de amores... de Diego de San Pedro, había meditado Whinnom que todas sus poéticas arengas no se correspondían en absoluto con el "prosaísmo» de sus actos, todo lo cual generaba una disonancia de lo más cómica. Arnalte mantenía una postura ovidiana en las lides del amor. De igual manera lo hacen Diomedes o Coridón. Las palabras de Whinnom, similares a las de Bubnova, pueden aplicarse perfectamente a nuestro autor y obra:

Un contraste absurdo y realmente cómico entre la conducta de Arnalte y los altos ideales que expone, así como entre los prosaicos detalles de algunos trozos de la narrativa y el alto estilo en que son descritos. Lo absurdo de esta novelita estriba en tales disonancias, pero queda por demostrar que San Pedro las notase... ${ }^{59}$

Por el contrario, Delicado, maestro todavía más perspicaz que Rojas a la hora de llevar la parodia a extremos, sí habría acudido a esa disonancia de forma concienzuda y alevosa, como sabedor de un recurso a explotar en mayor medida para generar la risa sardónica de un auditorio amigo.

De lo antedicho puede inferirse además que Delicado no solo conoció los cauces prosísticos que gozaban de enorme éxito en su momento

59.- Diego de San Pedro, Tractado de amores de Arnalte y Lucendal Sermón, Obras completas I [1491], edición de Keith Whinnom, Madrid, Castalia, 1973, p. 59. 
(novela sentimental, libros de caballerías o toda la estirpe celestinesca) sino que asumió los lugares tópicos, doctrinas y retóricas amorosas que fluían debajo de todos ellos para ridiculizarlos a su antojo. Como bien nos declara en el prólogo que antecede a su corrección del Amadís, sabía que aquellas obras que triunfaban en las editoriales romanas y venecianas contenían el "arte de los verdaderos enamorados $»^{60}$, y son sus funciones como editor las que avalan estas interferencias entre librillos de materia amorosa y su obra, al menos para subvertir paródicamente los influjos de los primeros cuando lo considerara necesario o divertido, tal ha quedado demostrados con los mamotretos III, IV o LV respectivamente. Así, la lectura de romances sentimentales o idilios caballerescos no es solo solaz y alivio para un autor enfermo de sífilis y postrado en el hospital, sino una propedéutica y ensayo para las futuras intertextualidades.

Como resultado, Delicado va abigarrando unos episodios de corte idealista entre todo el realismo carnavalesco y de baja estofa de la obra. Esta amalgama, que no es más que la grotesca conjunción de un polo superior y otro inferior, ya se manifestaba en una obra que guarda concomitancias con nuestra Lozana, como es El asno de Oro de Apuleyo (no de otro modo se entendería la fabulilla de Eros y Psique, cuento de cuño neoplatónico que desentona entre las calamidades de Lucio). Y, por poner solo un ejemplo entre otros tantos, se repite significativamente en La Garduña de Sevilla de Castillo Solórzano, donde Teresilla se sirve de la lengua y la retórica de la corte para entretener con fabulillas semejantes a un auditorio que luego será la diana de todas sus trapacerías.

Por accidente biográfico, Delicado no pudo ser lector o conocedor, como sí lo sería Alfonso de Ulloa, de novedades prosísticas y poéticas de enorme calado en los tiempos venideros, tales como la primera pastoral de Montemayor o la edición temprana de las poesías de Garcilaso ${ }^{61}$. Pe-

60.- Tatiana Bubnova, «Ediciones venecianas de Delicado: los libros de caballerías», en Actas del VII congreso de la AISO, vol. XV, edición de Anthony Close, Madrid, Iberoamericana, 2006, p. 115.

61.- Establecer un paralelismo entre las labores editoriales de Delicado y Ulloa, que son coterráneas y giran en torno a una nómina parecida de títulos, no deja de ser interesante. Delicado corrigió y editó en Venecia durante la década de los treinta libros tales como la Tragicomedia de Calisto y Melibea (1531, 1534), Cárcel de amor (1531), Los quatro libros de Amadís de Gaula (1534), Los tres libros del muy esforçado caballero Primaleon et Polendos su hermano, hijos del Emperador Palmerín de Oliva (1534) o enmendó aquellas letras que consideraba trastocadas para la Questión de amor de dos enamorados (1533). Con una diferencia de veinte años, en labor semejante se sumerge Alfonso de Ulloa cuando de nuevo editó la Cárcel de amor... con otras obras suyas (1553) o la Tragicomedia de Calisto y Melibea (1553), así como otros títulos, entre los que se encuentran Las obras "Juan de Segura, Blasco de Garay y Cristóbal de Castillejo, Processo de cartas de amores (1553), la Silva de varia lección de Pedro Mexía (1553) o La Diana de Jorge de Montemayor (1568). Según se ve, abundan tantas diferencias como paralelismos. Para lo relativo a las ediciones de Delicado puede consultarse el catálogo que se incluye en la temprana monografía de Hernández Ortiz (José A. Hernández Ortiz, op., cit, p. 20) o el trabajo de Bubnova (Tatiana Bubnova, "Delicado editor: lo propio y lo ajeno", en Actas del XIV congreso 
ro lo antedicho nos cerciora de que si algunas corrientes habían de dejar impresa una más honda huella en el polígrafo y vicario del valle de Cabezuela fueran los viejos libros de caballería, las ficciones sentimentales cuatrocentistas o esa Tragicomedia de Rojas que la crítica se afana en erigir como modelo al cual Delicado quiso enfrentarse o superar, cuando no homenajear simplemente como hipotexto con el que coincide en moldes formales, usos paremiológicos o ciertas técnicas dramáticas.

Como autor «moderno» que es, se le antoja divertido parodiar aquellas situaciones tópicas, motivos estructurales o usos retóricos tan acendrados en los viejos tratados y libros de amores que un auditorio conocía (y aborrecía) sobradamente como para percibir con rapidez las alusiones. A ellos remite por la vía sarcástica: Delicado los somete a escarnio, pone en solfa aquellos patrones. Es otro medio de embellecer deformando. Todo forma parte de su estrategia como iconoclasta:

\begin{abstract}
En realidad, la cultura, clásica y moderna, de Delicado está disimulada bajo la actitud desmitificadora hacia el canon, la ortodoxia, los convencionalismos, la hipocresía, así en ámbito literario como religioso (...) una práctica antiacadémica, burlesca y paródica cuya existencia se desenvolvió contradictoria y paralelamente a la armonía y al decoro de la literatura de impronta petrarquesca ( $y$ en Italia bembesca), generando una lengua baja y expresiva, mimética respecto a la lengua hablada y eminentemente dialógica ${ }^{62}$.
\end{abstract}

Con solo una aproximación somera a determinados pasajes hemos visto que ciertas intertextualidades (y aquí hemos hecho hincapié en las ovidianas, las del De amore, los tratados de medicina práctica o las ficciones erótico-sentimentales) descuellan a lo largo de la trama de la obra. Conforman retazos que cobran una importancia cabal por su mismo carácter paródico y por irse entreverando en el marco general de un Retrato que, sin todos estos lapsos risibles y sin sus burlas mordaces (siempre asociadas al amor, el deseo o el sexo) no hubiera salvado a su creador ni sería aún hoy la bocanada de aire fresco que fue en aquella Roma babilónica y del pecado.

Y bocanada de aire fresco que, a su protagonista y a su autor, les desasen momentáneamente de su cuadro melancólico-depresivo, que precisamente estas "cosas de amor» no solo diagnostican, sino que palían. Lozana y Delicado comparten el signo de Venus y Saturno: «si to-

de AIH, vol. II, coords., Isaías Lerner, Roberto Nival y Alejandro Alonso, Newark, Delaware, Juan de la Cuesta, 2004, pp. 51-58). Para lo relativo al enigmático personaje de Alfonso de Ulloa, véase el trabajo mentado (Antonio Rumeu de Armas, Alfonso de Ulloa, introductor de la cultura española en Italia, Madrid, Gredos, 1973, pp. 107-120).

62.- En la introducción de Perugini a: Francisco Delicado, op., cit, p. XL. 
da escritura es amorosa, toda imaginación es, abierta o secretamente, melancólica» ${ }^{63}$. Luego ya, se trata de combatir la melancolía con la escritura. El ritmo, la parodia y la elocuencia se zafan del silencio de la muerte y sacan al hombre de su abulia. Todo gracias a un Eros que sostiene, anima y mueve el mundo.

\section{Bibliografía citada}

Allaigre, Claude, Sémantique et littérature. Le Retrato de La Lozana Andalu$z a$ de Francisco Delicado, Echirolles, Imprimerie du Néron, Echirolles, 1980.

Alzieu, Pierre, Jammes, Robert, Lissorgues, Yvan, Poesía erótica del Siglo de Oro, Barcelona, Crítica, 1984.

Aretino, Pietro, Sonetos sobre los "XVI modos», edición y traducción de Pablo Luis Ávila, Colección Medio Maravedí, Islas Baleares, Universidad de las Islas Baleares, 1999.

—, Los diálogos del Divino Pedro Aretino generalmente denominados diálogos putescos, ahora por primera vez puestos de la lengua toscana en castellano [1534], estudio, traducción y notas de Joaquín López Barbadillo, Madrid, Akal Editor, 1978.

BaTJIn, Mijail, La cultura popular en la Edad Media y en el Renacimiento. El contexto de François Rabelais [1941], Madrid, Alianza, 1987.

BotTA, Patrizia, "La Celestina vibra en La Lozana», Cultura neolatina, 62 (2002), pp. 275-304.

Bubnova, Tatiana, Francisco Delicado puesto en diálogo: las claves bajtinianas de La Lozana Andaluza, México, Universidad Autónoma de México, 1987.

—, "Ediciones venecianas de Delicado: los libros de caballerías», en Actas del VII congreso de la AISO, vol. XV, ed., Anthony Close, Madrid, Iberoamericana, 2006, pp. 115-120.

—, "Delicado editor: lo propio y lo ajeno", Actas del XIV congreso AIH, vol. II, coords., Isaías Lerner, Roberto Nival y Alejandro Alonso, Newark, Delaware, Juan de la Cuesta, 2004, pp. 51-58.

CANET VAllÉs, José Luis, De la comedia humanística al teatro representable (Égloga de la tragicomedia de Calisto y Melibea, Penitencia de amor, Comedia Thbayda, Comedia Hipólita, Comedia Serafina), Madrid-Sevilla-Valencia, UNED, Universidad de Sevilla-Universidad de Valencia,1993.

Cantizano Pérez, Félix, «De las ninfas del Olimpo a las ninfas de las tasqueras: una visión de la prostitución en la España del Siglo de Oro", eHumanista, 15 (2010), pp. 154-175.

63.- Julia Kristeva, op., cit, p. 20. 
Capellán, Andrés el, De amore. Tratado sobre el amor, edición y traducción de Inés Creixell Vidal Quadras, Barcelona, El Festín de Esopo, 1985.

Castillo Solórzano, Alonso, Picaresca femenina de Alonso Castillo Solórzano, Teresa de Manzanares y La garduña de Sevilla, estudio y edición de Fernando Rodríguez Mansilla, Navarra, Iberoamericana, 2012.

Cátedra, Pedro Manuel, Amor y pedagogía en la Edad Media: estudios sobre doctrina amorosa y práctica literaria, Salamanca, Universidad de Salamanca, 1989.

Corriente, Federico, "Los arabismos de La Lozana Andaluza», Estudis Romànics, 32 (2010), pp. 51-72.

Costa Fontes, Manuel da, The art of subversión in inquisitorial Spain: Rojas and Delicado, Vol. 30, West Lafayette, Purdue, 2005.

Culianu, Ioan Petrus, Eros y magia en el Renacimiento: 1484 [1984], Madrid, Ediciones Siruela, 1999.

Criado Del Val, Manuel, "Antífrasis y contaminaciones de sentido erótico en La Lozana Andaluza», en AA.VV., Studia Philologica. Homenaje a Dámaso Alonso, I, Madrid, Gredos, 1960, pp. 431-458.

Delicado, Francisco, La Lozana Andaluza, edición de Claude Allaigre, Madrid, Cátedra, 1985.

- La Lozana Andaluza, edición de Tatiana Bubnova, Florida, Stockcero, 2008.

- La Lozana Andaluza, edición, estudio y notas de Folke Gernert \& Jacques Joset, Madrid, Real Academia Española, 2013.

- La Lozana Andaluza, edición de Carla Perugini, Sevilla, Fundación José Manuel Lara, 2004.

EgIDO, Aurora, "El Persiles y la enfermedad de amor» en AA.VV., Actas del II Coloquio Internacional de Cervantistas [Alcalá de Henares, 6-9 de noviembre de 1989], Barcelona, Anthropos, 1991, pp. 201-224.

Espantoso Foley, Augusta, "Técnica audiovisual del diálogo y Retrato de La Lozana Andaluza», en Actas del Sexto Congreso Internacional de Hispanistas, eds., A. M. Gordon y E. Rugg, Toronto, University of Toronto, 1980, pp. 258-260.

FICINo, Marsilio, De amore: comentario a "El Banquete» de Platón [1594], traducción y estudio preliminar de Rocío de la Villa Ardura, Madrid, Tecnos, 1989.

Foucault, Michel, Historia de la sexualidad I: la voluntad de saber [1976], Argentina-México, Ediciones Siglo XXI, 2002.

Fourouet-Reed, Linnette, Protofeminismo, erotismo y comida en La Lozana Andaluza, Maryland, Scripta Humanística, 2004.

FRANÇOIS, Jeromine, "Función de la intertextualidad bíblica en el Retrato de la Lozana Andaluza de Francisco Delicado», Celestinesca, 38 (2014), pp. 37-60. 
Gernet, Folke, Francisco Delicados Retrato de la Lozana Andaluza und Pietro Aretinos Sei Giornate. Zum literarischen Diskurs über die käufliche Liebe im frühen Cinquecento, Ginebra, Droz, 1999.

Gil Fernández, Juan, «Apuleyo y Delicado: el influjo de "El asno de oro» en «La Lozana Andaluza»», Habis, 17 (1986), pp. 209-219.

Gordon, Bernard de, Lilio de medicina: un manual básico de medicina medieval, edición de Brian Dutton y John T. Cull, Madison, Hispanic Seminary of Medieval Studies, 1991.

Goytisolo Juan, «Notas sobre La Lozana Andaluza», Triunfo, XXX, n. 6891 (1976), pp. 50-55.

Hernández Ortiz, José A, La génesis artística de La Lozana Andaluza, El realismo literario de Francisco Delicado, Madrid, Ricardo Aguilera, 1974.

IMPERIALE, Louis, "El auctor ante sus personajes en La Lozana Andaluza», en Lecturas y relecturas de textos españoles latinioamericanos, vol. V, edición de J. Villegas, Irvine, The Regents of the University of California, 1994, pp. 59-57.

-, "Escritura y erotismo en La Lozana Andaluza: la lengua que pega al cuerpo", La Corónica, 38.1 (Spring 2009), pp. 293-314.

Jiménez de URRea, Pedro Manuel, Penitencia de amor [1514], edición de Domingo Ynduraín, Madrid, Akal, 1996.

JOSET, Jacques, "Y contiene muchas más cosas que La Celestina», en Varia Hispanica: Estudios sobre literatura española e iberoamericana, coord., Bénédicte Vauthier, Salamanca, SEMYR, 2005, pp. 95-116.

-, "El «otro» humanismo de Francisco Delicado», en Francisco Delicado, La Lozana Andaluza, edición, estudio y notas de Folke Gernert y Jacques Joset, Madrid, Real Academia Española, 2013, pp. 353-370.

KrISTeVA, Julia, Sol negro. Depresión y melancolía [1987], Barcelona, Wunderkammer, 2017.

KuffNer, Emily, ««En el tocar está la virtud»: The Eros of healing in La Lozana Andaluza», La Corónica, 45.1 (2016), pp. 63-87.

Martínez Torrón, Diego, "Erotismos en La Lozana Andaluza», Espiral, 6 (1979) Madrid, Fundamentos, pp. 61-122.

Menéndez Pelayo, Marcelino, Orígenes de la novela, Edición nacional de las obras completas de Menéndez Pelayo [1905], vol. 16, Madrid, Consejo Superior de Investigaciones Científicas, 1943, [edición digital de Enrique Sánchez Reyes, Biblioteca Virtual Miguel de Cervantes: cervantesvirtual.com]

Navarro Durán, Rosa, "El Retrato de La Lozana Andaluza, una novela en clave», Beoiberística, I (2017), pp. 65-80.

- La Lozana Andaluza, un retrato en clave: pasquines históricos en la Roma Babilonia, Sevilla, Renacimiento, 2018. 
Olalla, Ángela. "Tú no has venido a Roma para soñar'. Algunas notas sobre La Lozana Andaluza», en AA. VV., Estudios sobre literatura y arte dedicados al profesor Emilio Orozco Díaz, II, Granada, Universidad de Granada, 1979, pp. 559-579.

Ovidio, Amores/Arte de amar, edición de Juan Antonio González Iglesias, Madrid, Cátedra, 1993.

Paglialunga de Tuma, Mercedes, "Erotismo y parodia social en La Lozana Andaluza», en La idea del cuerpo en las letras españolas: siglo XIII a XVII, ed., Dinko Cvitanovic, Bahía Blanca, Cuadernos del Sur, 1973, pp. 118-153.

Piouero Rodríguez, Álvaro, "Erotismo natural en La Lozana Andaluza: una visión traslaticia de la flora y la fauna en la obra de Francisco Delicado», eHumanista, 31 (2015), pp. 539-559.

Rabelais, François, Gargantúa [1534], edición de Alicia Yllera, Madrid, Cátedra, 2006.

Rumeu de Armas, Antonio, Alfonso de Ulloa, introductor de la cultura española en Italia, Madrid, Gredos, 1973.

Salas Barbadillo, Alonso Jerónimo de, La hija de Celestina [1612], edición de Enrique García Santo-Tomás, Madrid, Cátedra, 2008.

Salvador Miguel, Nicasio, "Huellas de La Celestina en La Lozana Andaluza», en AA. VV., Estudios sobre el Siglo de Oro. Homenaje a Francisco Ynduráin, Madrid, Editora Nacional, 1984, pp. 431-459.

SAn Pedro, Diego de, Tractado de amores de Arnalte y Lucenda/Sermón, Obras Completas I, edición de Keith Whinnom, Madrid, Castalia, 1973.

Sevilla Arroyo, Florencio, "El «autorretrato» de Lozana en La Lozana Andaluza», EPOS, XXX (2014), pp. 289-310.

Sierra MATUTE, Víctor, "La Lozana andaluza y el género picaresco: panorama crítico y algunos matices», Tonos Digital 21.0, 2011.

Silva, Feliciano de, La Segunda Celestina [1534], edición de Consolación Baranda, Madrid, Cátedra, 1988.

Torres Naharro, Bartolomé de, Comedias, edición, introducción y notas de Dean W. McPheeters, Madrid, Castalia, 1973.

Virgilio, Geórgicas, edición de Jaime Velázquez, Madrid, Cátedra, 1994.

WARDropper, Bruce W, "La novela como retrato: el arte de Francisco Delicado", Nueva Revista de Filología Hispánica, VII (1953) pp. 475-488.

WHinnom, Keith, "El género celestinesco: origen y desarrollo», en Literatura en la época del emperador, ed., V. García de la Concha, Salamanca, Universidad de Salamanca, 1988, pp. 119-130. 
